\title{
Nature seekers within the urban vicinity
}

\author{
Rosilawati, Z. ${ }^{*}$, Nikmatul Adha, N. ${ }^{1}$, Dian Sandri ${ }^{2}$, Faizah A. ${ }^{1}$, and Ibrahim M. ${ }^{1}$ \\ ${ }^{1}$ Department of Urban and Regional Planning, Faculty of Built Environment, University of Malaya, \\ 50603 Kuala Lumpur, Malaysia \\ ${ }^{2}$ Urban Studies and Planning Programme, Faculty of Arts and Social Sciences, University of Malaya, \\ 50603 Kuala Lumpur, Malaysia
}

* Corresponding Author

Name: Rosilawati Zainol

E-mail: rosilawatiz@gmail.com

Address: Department of Urban and Regional Planning, Faculty of Built Environment, University of Malaya, 50603 Kuala Lumpur, Malaysia

Contact No.: +603-26173006

Rosilawati Zainol (Rosilawati, Z.) servers as a Senior Lecturer in information technology in urban and tourism planning at the Department of Urban \& Regional Planning, Faculty of Built Environment, University of Malaya, Kuala Lumpur, Malaysia. Her works can be found at http://www.researcherid.com/rid/B-9603-2010

Co-Authors:

Nikmatul Adha, Nordin (Nikmatul Adha, N.) is a lecturer in public participation and currently attached to the Department of Urban \& Regional Planning, Faculty of Built Environment, University of Malaya, Malaysia. Her works can be found at http://www.researcherid.com/rid/B9251-2010 and she can be contacted at nikmatul@um.edu.my;

Dian Sandri (Dian, S.) is an alumni of the Urban Studies \& Planning Programme, Faculty of Arts \& Social Sciences, University of Malaya. She can be contacted at dian@ yahoo.com.my;

Faizah, Ahmad (Faizah, A.) is a senior lecturer in conservation and is currently attached to the Department of Urban \& Regional Planning, Faculty of Built Environment, University of Malaya, Malaysia. She can be contacted at faiz@um.edu.my.

Ibrahim, Mohd@Ahmad (Ibrahim, M.) is a senior lecturer in land use development and is currently attached to the Department of Urban \& Regional Planning, Faculty of Built Environment, University of Malaya, Malaysia. He can be contacted at ibrahimohd@um.edu.my.

\section{Acknowledgement}

The authors wish to thank the University of Malaya for a research grant allocation of RM34,000 under the grant reference no. RG046/09SUS. 


\section{Nature seekers within the urban vicinity}

This paper presents visitors' profile and motivation to Broga Hill, a nature-based attraction located at the fringe of Kuala Lumpur the capital city of Malaysia. The paper seeks to examine visitors' motivation for visiting the study area. The study adopts quantitative approach through self-administered questionnaire surveys and interviews. 100 respondents were randomly selected among those who visited Broga Hill. Non parametric tests were used to analyse the data since it was found to be not normally distributed. The findings reveals that Broga Hill is visited by nature seekers of various backgrounds who were willing to spend almost forty minutes to one hour climbing up the hill because of the fresh air and the beautiful scenery from the hilltop. These are the pull factors that motivate visitors' attraction to the hill. The paper concludes that natural forest within the urban vicinity such as Broga Hill should be preserved. Any new development encroaching green spaces within any urban vicinity should be reviewed rigorously.

Keywords: nature seekers; motivation; typology; recreation; push and pull

\subsection{Introduction}

Previous studies demonstrate a growing need for nature as a source of relaxation and recreation (Baur \& Tynon, 2010; Broussard et al., 2008; Chiesura, 2004; Maas, 2006; Matsuoka \& Kaplan, 2008; Nor Akmar, 2012) ; Cheisura 2004;), However, the enjoyment of nature is not obvious anymore. Rapid population growth and urbanisation across the globe have led to pressures on the natural landscape. Similarly, Malaysia is currently developing into an urbanised nation, with an expected urban population of $78 \%$ by 2030 (United Nation Habitat, 2012). Urban areas have recently experienced a decline in the quality and quantity of their green space (Gairola \& Noresah, 2010). Natural and open spaces have been lost due to the development of housing areas, infra-structure, commercial and industrial areas. Consequently, many available parks in the cities are getting congested (Ahmad, 2012), whilst those urban dwellers who love nature are willing to travel out of the city to enjoy and satisfy their recreational and leisure needs. Thus, this paper seeks to identify the urban dwellers' motivations to visit the nature based parks at the fringe of a city and also establish their profile.

This paper is organised as follows: in section 2 - recreational parks are described, section 3 - visitor's profiling and motivation are discussed consecutively, section 4 - data collection and method, section 5 results and followed by section 6 - discussion. The work of this paper is summarised in the final section.

\subsection{Recreational Parks}

Recreational parks in the city play a major role in providing public spaces where city dwellers spend time with their family members or neighbours and, at the same time, enjoy some fresh air. In certain parts of the city, children and youths spend most of their leisure time either at the parks or at home playing electronic games. Studies have shown that there is a strong relationship between outdoor activities and health (Dirani et al., 2009) and the environment (Franzini et al., 2010). Furthermore, studies have also shown that visualising green space such as trees and grass can help reduce anxiety level (Parnabas \& Mahamood, 2012), create positive moods (Hull IV, 1992), enable nature enjoyment (Sop Shin et al., 2005) and fulfil important immaterial and non-consumptive human needs (Chiesura, 2004). A park is a meeting place for people of diversified backgrounds and needs regardless of age, race and abilities 
(Thompson, 2002). Natural recreational areas in the cities such as urban forest, although are shrinking in numbers due to urban development, contribute to the quality of life of city dwellers in many ways (Chiesura, 2004), including as a source of positive feelings, a place where people are able to experience freedom, diversity, self-expression, challenges and enrichment (Faizi, 2006; Gold, 1980). Therefore, the availability of recreational parks is crucial in any city towards its inhabitants' health.

Cities developed in the early 20th century provide ample green spaces for public and recreational activities (Hinds, 1979). Developed nations have realized that the world needs to practice sustainable urban development due to decay on the environment. Brundtland Report in 1987 and United Nations Conference on Environment and Development (UNCED) in 1992 highlight the importance of securing global sustainable development (Bulkeley \& Betsill, 2003) by taking action at local level. However, in developing countries, during the late 20th century, cities were dispersed (Cohen, 2006) and filled with concrete built environment which provide fewer public spaces. Green spaces are limited to buffer zones and road dividers; less green spaces for human interaction. Community becomes less integrated and socially segregated. Demand for housing escalated due to the influx of people coming into the cities and, the fact that many green lungs have been surrendered for development. Furthermore, demand for highways and road-widening due to an increasing number of private vehicles also contribute to the decreasing number of green spaces. This chronology of events has no doubt made an impact on the global climate change issues being discussed today. Currently, climate change issues have become an eyeopener to people on the fact that there is a need to secure green areas in their cities. People are now aware that they are to protect available green spaces within their cities' vicinities (Bernama, 2012; Joint Action Committee for Bukit Gasing, 2012; Lim, 2011).

\subsection{Visitor's Profiling}

A visitor refers to any person taking a trip to any destination outside his/her usual environment, for less than a year, for any purpose other than for employment purposes (UNWTO, 2012). Visitors can be divided into two classifications, namely, domestic or international visitors and, excursionists or recreationists. Domestic visitor is a visitor who makes trips within a country. On the other hand, international visitor refers to a visitor who makes trips to other countries. Another classification of visitor is whether he/she is an excursionist or recreationist. The former refers to a person who makes a trip to more than one area within 24 hours, while the latter refers to any person who makes a trip for recreational activities. Urban dwellers fall into this category. They live in the city and are willing to travel away from the city in search for nature based destinations such as urban forest. They become refuges who are seeking for something that has different setting from everyday home and work environment (Hammitt, 2002).

Sop Shin et al. (2005) indicate that older and more highly educated people view urban forest as important to their well being. They engage in non-challenging activities. Their main activities include walking (Hunter, 2001), enjoy scenic beauty (Sop Shin, et al., 2005), jogging and cycling (Arnberger, 2006). 


\subsection{Visitor's Motivation}

Motivation plays a significant role in attracting visitors to a destination. Studies have shown that visitors' motivation, activities performed at destination, travel experience and overall satisfaction are highly related (Andrada II \& Deng, 2010; Armario, 2008; Pearce \& Lee, 2005; Yoon \& Uysal, 2005). It refers to "the need that drives an individual to act in a certain way to achieve the desired satisfaction (Beerli and Martin, 2004:626). Studies on visitor's motivation have been carried out by many scholars in various perspectives, namely, push and pull factor (Beerli \& Martín, 2004; Dann, 1977; Mohammad, 2010; Yuan \& Mcdonald, 1990), socio-psychological and cultural categorical factors (Crompton, 1979), tourist's motivation and behaviour (Fodness, 1994), the relationship between expectations and motivations (Gnoth, 1997) and psychological benefits of seeking and escaping interpersonal rewards and environments (Mannel \& Iso-Aloha, 1987). Motivation and human behaviour are interrelated. Emotional needs are the push factors and emotional benefits are the pull factors (Goossens, 2000). Push factors include feeling of pleasure, excitement and relaxation. Likewise, beautiful scenery, green and authenticity are the pull factors. Revisit intention is an extension of satisfaction (Um et al., 2006). From these literatures, it can be concluded that motivation and human behaviour are interrelated. Revisit intention is an extension of satisfaction (Um, et al., 2006).

\subsection{Methodology}

This study was carried out using quantitative approach. Primary data collection was carried out in March 2011 at the top of Broga Hill by using a self-administered questionnaire and interviews. A sample of 100 respondents, randomly chosen, was surveyed. These respondents are visitors of Broga Hill.

\subsection{Instrument}

The questionnaire consisted of three parts in which general attitudes towards Broga Hill and motives for visiting the area were gathered. There were questions on respondents' background (gender, age, education level, place of current residence, source of information and, details of their visits) to develop a Broga Hill visitor profile. There were questions asking respondents for their purpose of visiting Broga Hill and, the pull and push factors of the destination. The measurement used in this section is based on a Likert scale of 1 to 5 with 1 being 'most disagree' and 5 being 'most agree'. The main part of the questionnaire covers respondents' experience and feelings at the top of Broga Hill, and their willingness to revisit. Similar to section 2, a Likert scale of 1 to 5 with 1 being 'most disagreed' and 5 being 'most agreed' is used as measurement tool for this section. Furthermore, they were asked to identify five aspects that they most preferred and least preferred about Broga Hill. Frequencies, mean comparisons and non-parametric tests were used to provide the first view of the demographic profile and perceptions. .. The non-parametric tests include Crosstab, Mann-Whitney U and, Friedman's tests. For reliability, a Cronbach's Alpha score of 0.891 is applied. 


\subsection{Study Area}

Broga Hill, also known as Bukit Lalang to the locals, is located near University of Nottingham in Semenyih, Selangor. It is about 47 kilometres away from KLCC, Kuala Lumpur, 58 kilometres from Shah Alam - the capital city of Selangor and, 35 kilometres from Seremban - the capital of Negeri Sembilan. Located in Kampung Broga, Hulu Langat District, the hill sits on the border of Selangor and Negeri Sembilan. It is composed of various flora and fauna, especially tall grass, squirrels and birds. Its peak is 400 metres from sea level.

Broga Hill was chosen for this study because it is under the threat of surrounding urban development. In 2001, there was a plan to build a RM1.5 billion incinerator project in Broga. However, it was terminated in 2007 through court ruling (Loong \& Cheah, 2007). Nevertheless, the beautiful landscape might attract developers to develop it into an exclusive residential area, as in the case of Bukit Gasing area in Petaling Jaya (Ahmad, 2012; Bernama, 2012). This study intends to highlight the importance of preserving valuable and scarce green lung within the Klang Valley, by demonstrating the visitors' motivations for visiting the Broga Hill. Figure 1 shows the location of Broga Hill in relation to other city centres and townships.

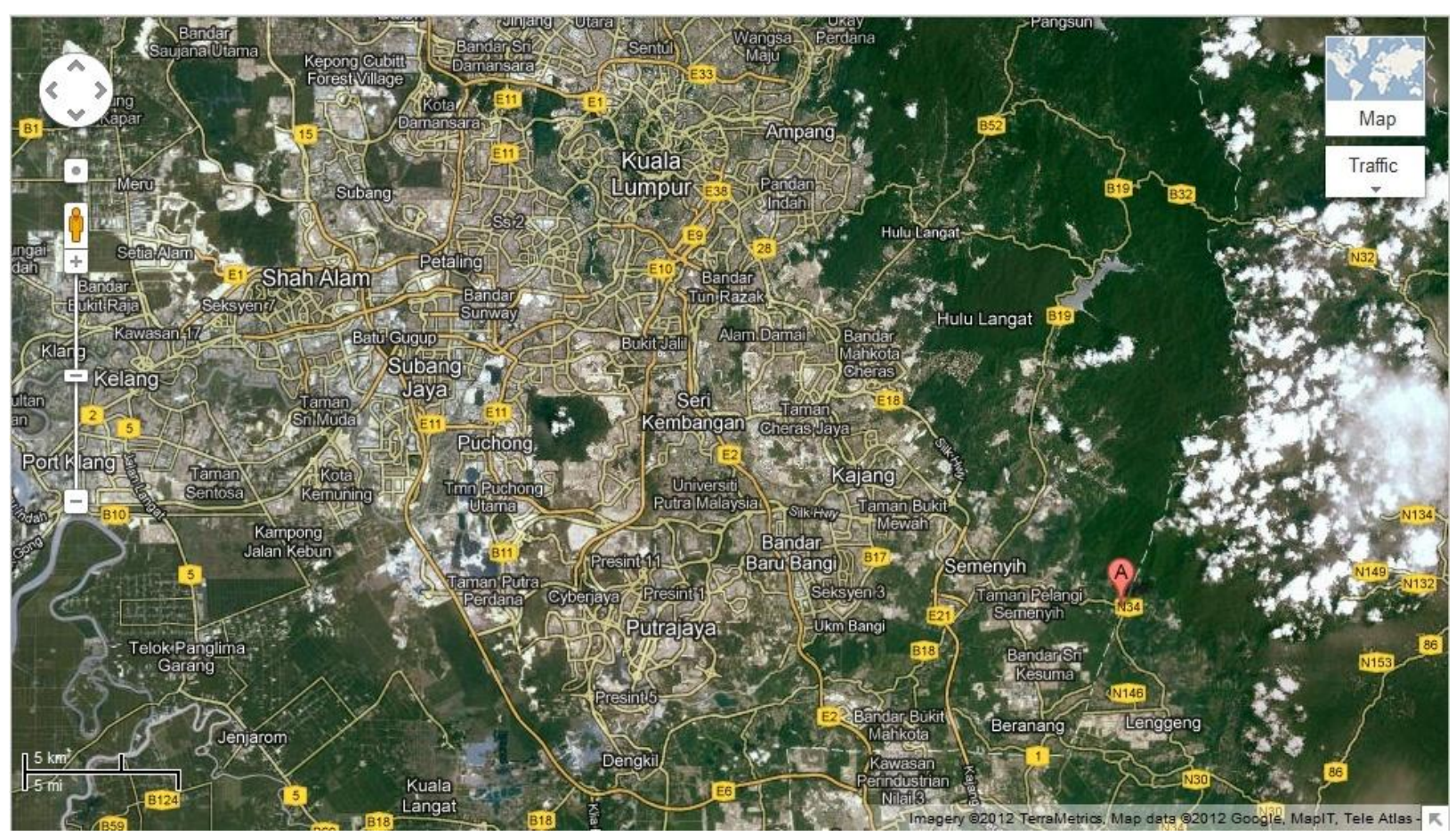

Figure1: Location of Broga Hill in relation to other cities and townships

(Source: Google Map 2012)

\subsection{Results}

100 respondents were surveyed over the period of two consecutive weeks. The following subsections discuss the findings of the survey. 


\subsection{Respondents' Profile}

The results reveal that the respondents are evenly distributed among gender groups. $79 \%$ of the respondents are within the working age-group between 20 and 60 years old. Mean age of the respondents is 23.96 with a minimum age of 14 years (3\%) and a maximum age of 48 years (1\%).

$97 \%$ of the respondents are Malaysians, with $66 \%$ of them residing in various townships within the Klang Valley. $71 \%$ of them knew about Broga Hills from friends and $95 \%$ of them went there in their own vehicles. The majority of them went in groups (89\%), $76 \%$ are first timers and chose weekends as the best time to visit the place. Some of the respondents even visited Broga Hill as early as 1 a.m. and the majority of them (58.5\%) reached the foot of the hill before 5 a.m. Most of them (40\%) took about 60 minutes to climb up the hill. Overall, $97 \%$ of them are willing to revisit Broga Hill in the near future.

\subsection{Visitors' Motivations}

The findings reveals eleven main motives for Broga Hill's visitors' to visit the area includes i) experience the challenge of climbing the hill; ii) to get closer to nature; iii) to enjoy the fresh air; ivi)to participate in sports activity; v) to enjoy the natural beauty; vi) to gain confidence, vii) to gain knowledge and experience; viii) to unwind; ix)to rest; xi) o gain social network; xii) to get away'. This is shown in the Friedman test where these eleven items score a mean rank of more than 7 . This test further reveals that all fourteen motives are significantly related $\left[\chi^{2}(13, \mathrm{~N}=100)=166.180, \mathrm{p}=.000\right]$. Table 3 shows details of the scores. The common ground for this relationship is to enjoy nature and to relieve stress.

In addition, Mann-Whitney $U$ test shows that there is no significant difference in motives between first timers and regular visitors and also between genders. However, there is a significant difference in terms of motives for visiting by age group. According to Kuskal-Wallis $\mathrm{H}$ test, a teenager has a higher mean rank (67.21) as compared to a young adult (42.74) and an adult $(48.98)\left[\chi^{2}(2, \mathrm{~N}=100)=10.726, p=.005\right]$.

\subsection{Pull Factors of Broga Hills}

The findings reveals five main pull factors of Broga Hill includes attractive, natural environment, natural structure, travelling and, attractive environment. This is shown by Friedman test in which these five items score a mean rank of more than 6.5. The test further demonstrates that all eleven pull factors perceived by the visitors are significantly related $\left[\chi^{2}(10, \mathrm{~N}=100)=175.738, \mathrm{p}=.000\right]$. The common ground of the relationship is still nature. Table 4 shows details of the scores. However, there is a significant difference in terms of safety by age group. Kruskal-Wallis test reveals that a teenager (65.17) scores a higher mean rank as compared to a young adult (42.65) and an adult (50.08) [ $\left.\chi^{2}(2, \mathrm{~N}=100)=8.678, p=.001\right]$. 
Table 1: Respondents' motives for visiting Broga Hill

\begin{tabular}{|c|c|c|c|c|}
\hline Motives for visiting & $\mathrm{N}$ & Mean & Std. Deviation & Mean rank \\
\hline to experience challenge & 100 & 4.45 & .809 & 8.72 \\
\hline to get closer to nature & 100 & 4.42 & .781 & 8.58 \\
\hline to enjoy fresh air & 100 & 4.41 & .780 & 8.42 \\
\hline to participate in sports activity & 100 & 4.44 & .756 & 8.42 \\
\hline to enjoy natural beauty & 100 & 4.36 & .927 & 8.35 \\
\hline to gain confidence & 100 & 4.31 & .884 & 8.01 \\
\hline to gain knowledge and experience & 100 & 4.29 & .844 & 7.96 \\
\hline to unwind & 100 & 4.29 & .844 & 7.87 \\
\hline to rest & 100 & 4.27 & .827 & 7.71 \\
\hline to gain social network & 100 & 4.00 & 1.146 & 7.16 \\
\hline to get away & 100 & 3.91 & 1.288 & 7.04 \\
\hline to take risk & 100 & 3.71 & 1.200 & 5.88 \\
\hline social status & 100 & 3.66 & 1.208 & 5.78 \\
\hline education & 100 & 3.58 & 1.084 & 5.13 \\
\hline \multicolumn{5}{|l|}{ Chi-Square $=166.180$} \\
\hline \multicolumn{5}{|l|}{$\mathrm{df}=13$} \\
\hline Asymp. Sig. $=.000$ & & & & \\
\hline
\end{tabular}

However, Mann-Whitney U test shows that there is a low significant difference between first timers and regular visitors in their views of recreational facilities $[\mathrm{U}(\mathrm{N}=100)=651.500, \mathrm{p}<.05(\mathrm{z}=2.172, \mathrm{p}=.030)]$ and considerable cost $[\mathrm{U}(\mathrm{N}=100)=660.000, \mathrm{p}<.05(\mathrm{z}=2.148, \mathrm{p}=.032)]$. First timers score a lower mean rank in recreational facilities, 47.07 as compared to regular visitors, 61.35 and in terms of reasonable cost, first timers score higher, 53.82 and regular visitors, 40.00. 63\% of regular visitors consider that recreational facilities as a pull factor as compared to $45 \%$ of first timers. Likewise, $72 \%$ of first timers agree that considerable cost is a pull factor as compared to $46 \%$ of regular visitors.

\subsection{Visitors' Activities}

The study reveals six main activities at Broga Hill include to appreciate nature's beauty, to try something new, to observe sunrise, to observe Hulu Langat area, to make new friends and, finally, to pamper myself. This is shown by Friedman test in which these six items score a mean rank of more than 2.69. In addition, the Friedman testalso demonstrates that the six activities carried out by the visitors are 
significantly related $\left[\chi^{2}(5, \mathrm{~N}=100)=90.338, \mathrm{p}=.000\right]$. The common ground for this relationship is about observing nature. Table 5 shows details of the scores.

Table 2: Respondents' opinion on the pull factors of Broga Hill

\begin{tabular}{lllll}
\hline Pull factors & $\mathrm{N}$ & Mean & Std. Deviation & Mean Rank \\
\hline attractive & 100 & 4.30 & .870 & 7.44 \\
natural environment & 100 & 4.25 & .809 & 7.30 \\
natural structure & 100 & 4.14 & .792 & 6.87 \\
travelling & 100 & 4.08 & .872 & 6.69 \\
attractive environment & 100 & 4.05 & 1.086 & 6.54 \\
reasonable cost & 100 & 3.97 & 1.068 & 6.42 \\
travel location & 100 & 4.24 & 4.829 & 5.70 \\
preserved environment & 100 & 3.63 & 1.195 & 5.33 \\
facility maintenance & 100 & 3.54 & 1.167 & 5.02 \\
recreational facilities & 100 & 3.45 & 1.158 & 4.83 \\
safety & 100 & 3.03 & 1.141 & 3.88 \\
\hline
\end{tabular}

Chi-Square $=175.738$

$\mathrm{df}=10$

Asymp. Sig. $=.000$

Table 3: Respondents' activities at the top of Broga Hill.

\begin{tabular}{lllll}
\hline Activities & $\mathrm{N}$ & Mean & Std. Deviation & Mean Rank \\
\hline appreciate nature's beauty & 100 & 4.33 & .805 & 4.30 \\
try something new & 100 & 4.19 & .961 & 4.17 \\
observe sunrise & 100 & 3.88 & 1.076 & 3.47 \\
observe Hulu Langat area & 100 & 3.69 & 1.002 & 3.27 \\
make new friends & 100 & 3.61 & 1.136 & 3.12 \\
pamper myself & 100 & 3.20 & 1.263 & 2.69 \\
\hline Chi-Square $=90.338$ & & & & \\
df $=5$ & & & & \\
Asymp. Sig. $=.000$ & & & & \\
\hline
\end{tabular}




\subsection{Visitors' Feeling and Preferences}

The findings highlights the common feelings of the visitors include freshen up body and mind, joyful journey, stress relieving, and, gaining invaluable experience. These four feelings rank more than 4 in a Likert scale of 1 to 5. Friedman test on these five items shows a mean rank score of more than 3.00. The Friedman test further shows that the five feelings are significantly related $\left[\chi^{2}(4, N=100)=33.416, p=\right.$ .000]. The common ground for this relationship is about body and mind relaxing. However, MannWhitney $U$ test shows that there is a significant difference between first timers and regular visitors in terms of gaining invaluable experience. First timers score a lower mean rank (47.37) as compared to regular visitors $(60.42)[\mathrm{U}(\mathrm{N}=100)=674, \mathrm{p}<.05(\mathrm{z}=2.056, \mathrm{p}=.040)$. Table 6 shows details of the scores on respondents' feelings being at the top of the hill.

Table 4: Respondents' feelings of being at the top of BrogaHill.

\begin{tabular}{lcccc}
\hline Respondents' feelings & $\mathrm{N}$ & Mean & Std. Deviation & Mean Rank \\
\hline freshen up body and mind & 100 & 4.34 & .742 & 3.31 \\
joyful journey & 100 & 4.20 & .816 & 3.09 \\
relieve stress & 100 & 4.21 & .820 & 3.07 \\
gain invaluable experience & 100 & 4.15 & .857 & 3.01 \\
sharpen my mind & 100 & 3.89 & .984 & 2.53 \\
Chi-Square $=33.416$ & & & & \\
df $=4$ & & & & \\
Asymp. Sig. $=.000$ & & & & \\
\hline
\end{tabular}

The findings highlights that the visitors preferred the natural beauty, fresh air, green and beautiful scenery, ability to relax and relieve stress, and, finally, good for health. On the other hand, the lack of basic facilities, garbage management, security, and signboards and also too many visitors were highlighted as the main shortcomings of Broga Hill.

\subsection{Discussion}

The findings of the survey indicate that urban nature fulfils important immaterial and non-consumptive human needs (Chiesura, 2004). People are attracted nature and it has beneficial effects on people (Schroeder, 1990). Results obtained accord with previous observations regarding people's need to experience nature (Kaplan \& Kaplan, 1989) regardless of their background (Thompson, 2002). Although Sop Shin et al. (2005) state that older people view outcome of urban forest experience as important, this study has proved that young people also find this experience significantly important especially when the destination is located at a higher ground and requires high stamina to reach it. 
People visit the park primarily because they want to relax. Chiesura (2004) also found relaxation as an important need fulfilled in nature, along with fascination, beauty, peace and freedom. The needs to experience nature and to escape from the stressful rhythm of the city also constitute important reasons for people's visits to the park. These are the push factors as mentioned by Goossens (2000) experienced by the visitors of Broga Hill. Furthermore, findings show that the experience of nature in the city is source of a large array of positive feelings to people. Viewing and engaging with nature which are the main activity at the peak of the hill also result in feelings of pleasure, enjoyment, relaxation, comfort and calmness (de Vries et al., 2003; Korpela et al., 2002; Lohr, 2011). These are the pull factors of a destination (Goossens, 2000) and this study proves that Broga Hill has them.

Study results show differences and similarities in terms of preferred activities, experiences and attributes of green space. The most popular reasons for visiting green spaces include finding peace and quiet, relaxation and enjoying nature and fresh air. Revisit intention among the visitors of Broga Hill shows their extension of satisfaction. These are consistent with the findings of previous studies (Chiesura, 2004; Jim \& Chen, 2006; Sanesi \& Chiarello, 2006; Schipperijn et al., 2010; Um, et al., 2006).

\subsection{Conclusion}

In the context of this study, the role of urban forest as provider of social services and their importance for urban dwellers has been addressed. Some results have been presented of a survey aimed at exploring the motives and perceptions of visitors of a Malaysian urban forest. Due to the small size of the sample analysed and the limited statistics performed, no universal conclusions can be consistently made about the role of urban forests in general.

However, some conclusive remarks can be made. Firstly, urban nature fulfils many social functions and psychological needs of urban dwellers, which then emphasizes the importance of urban nature as a valuable municipal resource. It adds to the previous related studies which have proved that there is a link between nature based destination and human psychological needs (Hammitt, 2002). Secondly, different age-groups have different motives to visit the park and different activities they are going to undertake. Their main intention of visiting this nature based attraction is to breathe fresh air, to appreciate the natural beauty of sunrise and scenery, and to relieve stress. Thus, natural scenery and green visualisation are able to reduce stress as described by Parnabas and Mahamood (2012), create positive moods (Hull IV, 1992), fulfil important immaterial and non-consumptive human needs (Chiesura, 2004), and enable nature enjoyment (Sop Shin, et al., 2005).

Travel motivation, destination attributes and visitor's behaviour are related to each other and have an influence on visitor's satisfaction. This is proven by the high number of respondents who are willing to revisit Broga Hill. This finding is also consistent with findings by Um et al. (2006) which stated that perceived attractiveness is the main motive for revisit intention rather than overall satisfaction. In addition, level of novelty-seeking also contributes to revisit intention (Mahasuweerachai \& Qu, 2011). Since nature based destination is diminishing, city dwellers will choose any available destination near 
them to fulfil their recreational needs. When this happens, these limited destinations will be overcrowded and face carrying capacity issue.

It is timely that available nature based destinations in the cities be preserved to meet city dwellers' recreational needs. Its deconstruction may cause negative externalities (Tyrväinen \& Väänänen, 1998). Urban forests require low maintenance, self sustaining, less tailored and care for (Justice, 1986). Therefore urban forests which are located within urban vicinity should be preserved. Since the existence of urban forest has positive correlation with the well being of its visitors, any new development should take into account the people's public space for leisure activities within their reach. In addition, this destination should be managed efficiently such as basic facilities, garbage management, security, signboards and repackaged Borga Hill as one of the state of Selangor tourist's attractions. Further research on the importance of and demands for urban green spaces from residents' and visitors' perspectives in relation to climate change issues should be carried out.

\subsection{References}

Ahmad, A. (2012, July 8). Walks in the park no more? New Sunday Times, p. 16.

Andrada II, R., \& Deng, J. (2010). Enjoying green cities: assessing visitors' attitudes and preferences for urban forests in Washington, D. C. Paper presented at the Northeastern Recreation Research Symposium.

Armario, E. M. (2008). Tourist satisfactionan analysis of its antecedents Paper presented at the Asociación Europea de Dirección y Economía de Empresa. International Conference, Salvador de Bahía.

Arnberger, A. (2006). Recreation use of urban forests: An inter-area comparison. Urban Forestry \&amp; Urban Greening, 4(3-4), 135-144.

Baur, J. W. R., \& Tynon, J. F. (2010). Small-scale urban nature parks: why should we care? Leisure Sciences, 32, 195-200.

Beerli, A., \& Martín, J. D. (2004). Tourists' characteristics and the perceived image of tourist destinations: a quantitative analysis - a case study of Lanzarote, Spain. Tourism Management, 25(5), 623-636.

Bernama. (2012, March 13). Bkt Gasing residents to to federal court over development order. The Star.

Broussard, S. R., Washington-Ottombre, C., \& Miller, B. K. (2008). Attitudes toward policies to protect open space: A comparative study of government planning officials and the general public. Landscape and Urban Planning, 86(1), 14-24.

Bulkeley, H., \& Betsill, M. M. (2003). Cities and climate change: urban sustainability and global environmental governance. London: Routledge.

Chiesura, A. (2004). The role of urban parks for the sustainable city. Landscape and Urban Planning, 68(1), 129-138.

Cohen, B. (2006). Urbanization in developing countries: current trands, future projections, and key challenges for sustainability. Technology in Society, 28, 63 - 80.

Crompton, J. L. (1979). Motivations for pleasure vacation. Annals of Tourism Research, 6(4), 408-424.

Dann, G. M. S. (1977). Anomie, ego-enhancement and tourism. Annals of Tourism Research, 4(4), $184-$ 194.

de Vries, S., Verheij, R. A., Groenewegen, P. P., \& Spreeuwenberg, P. (2003). Natural environments -healthy environments? An exploratory analysis of the relationship between greenspace and health. Environment and Planning A, 35(10), 1717-1731.

Dirani, M., Tong, L., Gazzard, G., Zhang, X., Chia, A., Young, T. L., et al. (2009). Outdoor activity and myopia in Singapore teenage children. Br J Ophthalmol, 93, 997-1000.

Faizi, M. (2006). The role of urban parks in a metropolitan city. Environmental Sciences, 12, 29 - 34.

Fodness, D. (1994). Measuring tourist motivation. Annals of Tourism Research, 21(3), 555-581.

Franzini, L., Taylor, W., Elliot, M. N., Cuccaro, P., Tortolero, S. R., Gilliland, M. J., et al. (2010). Neighborhood characteristics favorable to outdoor physical activity: disparities by socioeconomic and racial/ethic composition. Health \& Place, 16, 267 - 274. 
Gairola, S., \& Noresah, M. S. (2010). Emerging trend of urban green space research and the implications for safeguarding biodiversity: a viewpoint. Nature and Science, 8(7), 43-49.

Gnoth, J. (1997). Tourism motivation and expectation formation. Annals of Tourism Research, 24(2), 283-304.

Gold, S. M. (1980). Recreation planning and design. New York: McGraw-Hill.

Goossens, C. (2000). Tourism information and pleasure motivation. Annals of Tourism Research, 27(2), 301-321.

Hammitt, W. E. (2002). Urban forests and parks as privacy refuges. Journal of Arboriculture, 28(1).

Hinds, D. B. (1979). The evolution of urban public park design in Europe and America : Vancouver adaption to 1913 Unpublished Master of Arts, University of British Columbia.

Hull IV, R. B. (1992). Brief encounters with urban forests produce moods that matter. Journal of Arboriculture, 18(6), 322 - 324.

Hunter, I. R. (2001). What do people want from urban forestry?-The European experience. Urban Ecosystems, 5(4), 277-284.

Jim, C. Y., \& Chen, W. Y. (2006). Impacts of urban environmental elements on residential housing prices in Guangzhou (China). Landscape and Urban Planning, 78(4), 422-434.

Joint Action Committee for Bukit Gasing. (2012, March 28). Whilst DBKL talks of "taman-taman \& jalinan hijau" and "river of life", damage to Bukit Gasing and flooding continues...

Justice, C. L. (1986). The concept of the urban forest as applied to Kuala Lumpur, Malaysia. Journal of Arboriculture, 12(7), 178-181.

Kaplan, R., \& Kaplan, S. (1989). The experience of nature: A psychological perspective. . New York: Cambridge University Press.

Korpela, K. M., Klemettilä, T., \& Hietanen, J. K. (2002). Evidence for Rapid Affective Evaluation of Environmental Scenes. Environment and Behavior, 34(5), 634-650.

Lim, C. Y. (2011, 8 June). Subang ria park stays. The Star.

Lohr, V. I. (2011). Greening the human environment: The untold benefits Acta Horticulturae, 916, 159169.

Loong, M. Y., \& Cheah, R. (2007, July 6). Broga incinerator project called off. The Star.

Maas, J., Verheij, R.A, Groenewegen, P.P, de Vries, S, Spreeunmenberg. (2006). Green space, urbanity, and health: how strong is the relation? J Epidemiol Community Health, 60, 587-592.

Mahasuweerachai, P., \& Qu, H. (2011). The moderating effects of tourists' characteristics and novelty seeking on the relationships between satisfaction, revisit intention and WOM. Paper presented at the 16th Graduate Students Research Conference, Houston, Texas.

Mannel, R. C., \& Iso-Aloha, S. E. (1987). Psychological nature of leisure and tourism experience. Annals of Tourism Research, 14, 314 - 331.

Matsuoka, R. H., \& Kaplan, R. (2008). People needs in the urban landscape: Analysis of Landscape And Urban Planning contributions. Landscape and Urban Planning, 84(1), 7-19.

Mohammad, B. A. M. A.-H. (2010). An analysis of push and pull travel motivations of foreign tourists to Jordan. International Journal of Business and Management, 5(12), $41-50$.

Nor Akmar, A. A. (2012). Green space use and management in Malaysia. Forest \& Landscape Denmark, Frederiksberg, 51-2012.

Parnabas, V. A., \& Mahamood, Y. (2012). Anxiety and imagery of green space among athletes. British Journal of Arts and Social Sciences, 4(1), 67 - 72.

Pearce, P. L., \& Lee, U.-I. (2005). Developing the Travel Career Approach to Tourist Motivation. Journal of Travel Research, 43(3), 226-237.

Sanesi, G., \& Chiarello, F. (2006). Residents and urban green spaces: The case of Bari. Urban Forestry \& Urban Greening, 4(3-4), 125-134.

Schipperijn, J., Stigsdotter, U. K., Randrup, T. B., \& Troelsen, J. (2010). Influences on the use of urban green space - A case study in Odense, Denmark. Urban Forestry \&amp; Urban Greening, 9(1), 25-32. 
Schroeder, H. W. (1990). Perceptions and preferences of urban forest users. Journal of Arboriculture, 16(3), 58-61.

Sop Shin, W., Gyo Kwon, H., Hammitt, W. E., \& Soo Kim, B. (2005). Urban forest park use and psychosocial outcomes: A case study in six cities across South Korea. Scandinavian Journal of Forest Research, 20(5), 441-447.

Thompson, C. W. (2002). Urban open space in the 21st century. Landscape and Urban Planning, 60(2), 59-72.

Tyrväinen, L., \& Väänänen, H. (1998). The economic value of urban forest amenities: an application of the contingent valuation method. Landscape and Urban Planning, 43(1-3), 105-118.

Um, S., Chon, K., \& Ro, Y. (2006). Antecedents of revisit intention. Annals of Tourism Research, 33(4), 1141-1158.

United Nation Habitat. (2012). UN Habitat for a better urban future. Retrieved 30 May 2012, 2012, from http://www.unhabitat.org/categories.asp?catid=671\&q=urban\%20population

UNWTO, W. T. O. (2012). Understanding tourism: basic glossary. Retrieved 20 Jun, 2012

Yoon, Y., \& Uysal, M. (2005). An examination of the effects of motivation and satisfaction on destination loyalty: a structural model. Tourism Management, 26(1), 45-56.

Yuan, S., \& Mcdonald, C. (1990). Motivational determinates of international pleasure time. Journal of Travel Research, 29(1), 42-44. 